Gerontologia 1967;13:193

\title{
In Memoriam Clive M. McCay
}

March 21, 1898 -June 8, 1967

Prof. Clive M. McCay died June 8, 1967 after a long illness, at his home in Engle-wood, Florida. After finishing his studies in biochemistry on the University of Illinois, and Ph.D. from the University of California, followed studies in Yale and Oxford. Since 1936 he was professor of Animal Nutrition at Cornell University in Ithaka, N.Y. He retired in 1962.

"Gerontologia" looses with him one of his editors, who served it since the beginning. His main interest was the influence of nutrition on aging. His work was recognized by his election as president of the American Gerontological Society and also of the American Institute of Nutrition. He was famous for his experiments which showed the prolongation of lifetime of rats if their diet was reduced from what they were eating spontaneously. [J.Nutr. 10: 63 (1935), $18: 1$ (1939), 21: 45 (1944), etc.]

His and his associates' work had a great influence on human nutrition in relation to aging and many discussions arose on its meaning. Later he continued this work on a large colony of aged dogs. His book on "Dog Nutrition" was much appreciated. His nutrition research led him also to important work with the U.S.Navy and the development of an improved bread.

He shall be remembered by his many pupils and friends. F.Verzár 13 Gerontologia, Vol. 13, No. 4, 1967 